\title{
Üçüncü Umumi Müfettişliği’nin Kurulması ve III. Umumî Müfettiş Tahsin Uzer'in Bazı Önemli Faaliyetleri
}

\author{
Yrd.Doç.Dr.Erdal AYDOĞAN*
}

\section{ÖZET}

Genel müfettişlikler Türkiye'deki sosyal, ekonomik ve idari şartların bir sonucu olarak, Türk idari tarihinde ortaya çıkan çok önemli politik ve idari kuruluşlardır. Bu kuruluşlar II. Abdulhamit' in hükümdarlı̆̆ı döneminde, II. Meşrutiyet döneminde ve Milli Mücadele döneminde tartışılmıştır.

Cumhuriyet döneminde, Doğu ve Güneydoğu Anadolu'daki azgelişmişliği, fakirliği ve ulaşım imkansızlıklarını ortadan kaldırmak için genel müfettişliklerin yeniden kurulması bir zorunluluk haline gelmiştir. Genel müfettişlikler bu bölgelerde Türk Hükümeti'nin gözü kulă̆ı olarak, kamu düzenini ve asayişi koruyacak ve bölgeyi geliştirmek için sıkı bir şekilde çalışacaktı.

1930'larda Türkiye'de meydana gelen gelişmeler, Başbakan İsmet İnönü'yü bazı tedbirler almaya itmişti. Böylece, Doğu Anadolu'da yeni bir genel müfettişlik kurulması bir zorunluluk haline gelmişti. Bu mïfettişliin merkezi Erzurum'da olacak ve müfettişlik Ağrı, Kars, Artvin, Rize, Trabzon, Gümüşhane, Ercincan ve Erzurum vilayetlerinden sorumlu olacaktı. Bakanlar Kurulu, 1935 yılında, 1164 numarall ve 25 Haziran 1927 tarihli kanun gereğince, bu vilayetlerde Üçüncü Genel Müfettişlik kurulması meselesini ele aldı. Aynı kabine, Türkiye Büyük Millet Meclisi'nde Erzurum Milletvekili olarak görev yapan Tahsin Uzer'I, 23 Ağustos 1935'te bu yeni kuruluşa genel müfettiş olarak atad. Böylece, 6 Eylül 1935'te Üçüncü Genel Müfettişlik resmen kurulmuş oldu.

Anahtar Kelimeler: Genel Müfettişlik, Doğu Anadolu, İsmet İnönü, Erzurum, Tahsin Uzer

\footnotetext{
- Atatürk Üniversitesi, Atatürk Illkeleri ve İnkılâp Tarihi Enstitüsü.
} 


\section{ABSTRACT}

General inspectorships are very important political and administrative establishments which arised in Turkish administrative history as a result of social, economical and managerial conditions in Turkey. These establishments were disputed in the period of sovereignity of Abdulhamit II, constitutional era II. And also the National Struggle Era.

In the Republic term in Turkey, it was felt obliged to be rebuilt of general inspectorships in order to take away the underdevelopment, poverty and impossibility on the circulation in Eastern and South-east Anatolia. The general inspectorships would be all eyes and ears of Turkish government in these region, maintain the public order and securitiy and strive hard to make these regious developed.

The events in Turkey in 1930's caused Ismet Inonu, prime minister, to take measures. So, it was obliged to organized a new general inspectorship in Eastern Anadolia. The head-office of this inspectorship would be in Erzurum. This inspectorship would be responsible in the provinces Agrt, Kars Artvin, Rize, Trabzon, Gumushane, Erzincan and Erzurum. In 1935, the Turkish cabinet handled the establishineg of the third general inspectorship in these provinces according to the law numbered 1164 and dated 25 June 1927. The same cabinet also appointed Tahsin Uzer, the Erzurum deputy in the Turkish National Assembly, as inspector general to this new unit in 23 August 1935. So, the Third General Inspectorship was built formally in 6 September 1935.

Key Words: General inspectorship, Eastern Anatolia, Ismet Inonu, Erzurum, Tahsin Uzer

Umûmî Müfettişlikler, Türk idare tarihinde hayat bulmuş, ülkede yaşanan sosyo-ekonomik ve idari şartların getirmiş olduğu önemli siyasi ve idari yapılanmalardır. Koçak'ın ifadesiyle bu yapılanma aynı zamanda "Osmanlı siyasi ve idari zihniyetinin ve uygulanmasının Cumhuriyete devreden mirası olarak kabul edilebilir"l. II.Abdülhamid devrinden 1952'lere kadar değişik isimler altında varlığını sürdürebilen müfettişlikler zamana ve şartlara göre "Umumi Valilik, Eyalet Valiliği, Genel Valilik, Fevkalade Valilik, Hidivlik, Bölge Valiliği, Süper Vali, Inspektörlük, Genel Müfettişlik" gibi isimlerle adlandırılmışlardır².

Umumi Müfettişlikler II. Abdülhamid ve II.Meşrutiyet Dönemlerinde olduğu gibi Milli Mücadele Döneminde de tartışılmıştır. Özellikle 1921 Teşkilat-1 Esasiye Kanunu'nun 22. ve 23. maddelerinde Umumi Müfettişlik

1 Cemil Koçak, Umumi Müfettişlikler (1927-1952), İstanbul, 2003, s.25.

2 Hüseyin Koca, Yakın Tarihten Günümüze Hükümetlerin Doğu-Güneydoğu Anadolu Politikalart, Konya, 1998, s.36. 
teşkilatlarının kurulması hususunda kanuni alt yapısı hazırlanmış ${ }^{3}$ ancak o günkü şartlar gereğince herhangi bir sonuç alınamamıștı. Bu tartışmalara katılan Kâzım Karabekir, Doğu harekatının başarısından sonra Ankara'ya davet edilmiş ve kendisine Müdafaa-i Milliye Vekaleti teklif edilmişti. Karabekir anılarında bu gelişmeleri şöyle anlatır: "Geçen yıl hazırlandığ halde, hala meclise sevk olunmadığını öğrendiğim Müfettiş-i Umûmilik Kanunu'nun bir an önce çıkarılması lüzumunu Müdafaa-i Milliye Vekaleti'yle Erkân-1 Harbiye-i Umumiye Reisliği’ne yazdım. Şifahen de bu makamlara bunun ve diğer şûraların lüzumunu anlattım. Bana hak veriyorlar. Fakat işler yürümüyor"4.

Yeni kurulmuş olan devlet, varlığını güçlendirmek için asıl mücadelenin cehalete ve geri kalmışlığa verilmesi gerektiği gerçeğinden hareketle zamanı ve şartları geldiğinde yapmayı düşündüğü inkılâplar hayata geçtikçe olumlu ve olumsuz tepkileri de beraberinde getirmiştir. Bu gelişmelere paralel olarak 1924 Anayasası'nda da Müfettişlik yönetimi hususunda herhangi bir düzenleme yapmamıştı. Ancak Doğu ve Güneydoğu Anadolu 1924'te önce Nasturi sonra Şeyh Said isyanlarının vukubulması hükümeti bu bölgelerde bazı idari reformlar yapılması hususunda mecbur bırakmıştı ${ }^{5}$. İlk etapta çeşitli sebeplerle başka bölgelere mecburi iskana tabi tutulanlardan bazılarının geri dönemlerine müsaade edilmiş, sonra 3. Ordu Müfettişliği'nden beklenen idarî ve sosyal anlamda yapılması gereken faaliyetlerin yetersizliği gibi sebeplerden dolayı yeni arayışlara girildi. O günkü şartlara ulaşım imkansızlıkları, bölgeler arasındaki kalkınmışlık farkları, yapılması gereken idari ve sosyal çalışmaların yapılamaması ve koordinasyonsuzluk, Doğu ve Güneydoğu Anadolu bölgelerinde bu gibi çalışmaları yapacak, hükümetin gözü kulağı olacak ve asayişin temini maksadıyla Umumi Müfettişliklerin yeniden kurulması bir mecburiyet haline gelmişti ${ }^{6}$. Goloğlu ise bu saiklerin yanında asıl belirleyici sebebin ekonomik olduğunu vurgulamaktadır. Cumhurbaşkanı ve ekonomi Bakanı Celal Bey'in yurt gezilerinin sonunda verildiğini söylediği bu kararın gerekçesini şöyle izah eder:

"Türkiye'nin her yanında aynı ekonomik koşullarla ilerlenemeyeceğinden memleket ekonomik bölgelere ayrılacak ve idare

3 "Vilayetler iktisadi ve içtimâ̂ münasebetleri itibariyle birleştirilerek umumi müfettişlik kıtaları vücuda getirilir” Teşkilat-ı Esasiye Kanunu'nun 22 Maddesi'ne göre bu teşkilatın gerekçeleri şöyle izah edilmiştir: Suna Kili, Türk Anayasaları, İstanbul, 1982, s.38.

4 Kâzım Karabekir, Paşaların Kavgası, İnkılâp Hareketlerimiz, İstanbul, 1995, s.244.

“Ankara Umum Müfettişlikten hidivlik diyerek korkuyormuş". Kazım Karabekir, Istiklal Harbimiz, İstanbul, 1990, s.1060.

5 Cumhuriyet idaresince vilayetler dışında liva statüsündeki bütün mülki idare üniteleri de vilayet yapılınca, vilayet sayısı 74 oldu. Koca, Yakın Tarihten Günümüze..., s.162.

Koca, Yakın Tarihten Günümüze..., s.164-165; M.Kalman, Belge ve Tantklartyla, Dersim Direnişleri, İstanbul, 1995, s.136. 
mekanizması da buna uydurularak her bölgede ayrı örgütler kurulacaktır. Üçer beşer ilden meydana gelecek bölgelerde bu illerin özel bütçelerinin birleşmesi sayesinde ihraç iskelelerinin, yolların ve benzeri şeylerin kolaylıkla gerçekleştirilmesi sağlanacaktır",

Netice itibariyle II. TBMM'nin son günlerinde 25 Haziran 1927 tarih ve 1164 sayılı, "Umumi Müfettişlik Teşkiline Dair" bir kanun çıkaracaktır. Tuncay'ın bölge valiliği (eyalet)'ne benzettiği bir sistemle sıkıyönetimin yerini dolduracak bir yetki yaratılmak istenmiş, Doğu Vilayetleri için Müfettişlik ihdas edilerek Dr.İbrahim Tali Bey'de bu önemli göreve atanmıştır ${ }^{8}$.

I. Umumi Müfettişliğin kurulmasına müteakip Edirne, Kırklareli, Tekirdağ ve Çanakkale vilayetlerini kapsayan ve bölgeler arasında iktisadi bayındırlık ve sosyal dengesizliklerin ortadan kaldırılması amacıyla II. Umumi Müfettişlik kurulmuş. Dr. İbrahim Tali Bey de 18.03.1934 tarihinde yeni görevine atanmıştı ${ }^{9}$.

Ülkede bu gibi idari yapılanmalar devam ederken Başbakan İsmet İnönü 1935 yılında Doğu ve Güneydoğu Anadolu ile Karadeniz Bölgesi'ni kapsayan bir inceleme gezisine çıkar. "İncelemelerinde Umumi Müfettişliğin yaptığı hizmetleri takdire şayan gören Başvekil İsmet Paşa gezi sonunda hazırladığı ünlü "Kürt Raporu"nu Atatürk ve Bakanlar Kurulu'na sundu"10. İnönü, raporunda en dikkat çekici tarafı "Doğu İlleri verimli bir hale gelmedikçe bütçenin ve devlet kudretinin artması beklenemez" demekteydi. Bunun gerçekleşmesi içinde Genel İnspektörlük müessesesinin kaçınılmaz olduğunu vurguluyordu. Olağanüstü Hal Bölge Valiliği olarak da tanımlanabilecek olan bu yapıda Umumi Müfettişlerin yetkilerini izah eden İnönü’ye göre Birinci Genel Müfettişlikten başka merkezi Erzurum olacak olan 3. Genel Müfettişlik teşkilatının kurulmasını bölgenin geleceği için kaçınılmaz görüyor ve bu çerçevede Ağrı, Kars, Artvin, Rize, Trabzon, Gümüşhane, Erzincan ve Erzurum vilayetlerinin bu yapı içinde olmasının önemini vurguluyordu" ${ }^{11}$.

İsmet İnönü'nün bu raporu doğrultusunda hayati önem atfedilen yeni bir müfettişlik bölgesinin kurulması böylece gerçekleştirilmiş olacaktı. 25 Haziran 1927 tarihli ve 1164 numaralı kanunun birinci maddesi mucibince

7 "Bundan başka, idare kuruluşlarının ekonomik esaslara göre çalışmaya yönetilmesi de tasarlanmaktadır" Mahmut Goloğlu, Tek Partili Cumhuriyet (1931-1938), Ankara, 1974, s.49-50.

8 Mete Tunçay, T.C'nde Tek Parti Yönetiminin Kurulması (1923-1931), İstanbul, 1992, s.174-175.

$9 \quad$ Koca, Yakın Tarihten Günümüze..., s.174-175.

10 Saygı Öztürk, İsmet Paşa'nın Kürt Raporu”, Hürriyet, (7 Eylül 1992), Koca, Yakın Tarihten Günümüze..., s.175. 1992).

" Saygı Öztürk, "21 Ağustos 1935 İsmet Paşa'nın Kürt Raporu”, Hürriyet, (10 Eylül 
Üçüncü bir Umumi Müfettişlik kurulması Bakanlar Kurulu'nda görüşülmüş̧ ${ }^{12}$ ve 23 A ğustos 1935 yılında da Umumi Müfettişliğe yine Bakanlar Kurulu kararıyla Erzurum Milletvekili Tahsin Uzer atanmış ${ }^{13}$ ve 6 Eylül 1935’te de 3. Umumi Müfettişlik resmen kurulmuş oluyordu.

Üçüncü Umumi Müfettişliğe atanan Tahsin Uzer, bölge halkının yakından tanıdı̆̆ı birisiydi. Daha I. Dünya Savaşı yıllarında Van'da, Erzurum'da yapmış olduğu valiliklerde ortaya koyduğu özveri bölge halkını ziyadesiyle memnun etmiş, günün şartlarında aranan idarecilerden olmuştu. İşte Tahsin Uzer'in yeniden bölgeye tayin olunması karşısında halk ve belediyeler kendisine kutlama telgrafları çekmiş, böylece duydukları memnuniyeti ifade etmişlerdi ${ }^{14}$.

Yaşanan gelişmeler karşısında Tahsin Bey de 15 Eylül 1935 tarihinde bir telgraf çekerek duygularını ve müfettişlik programı hakkında birtakım açıklamalarda bulunmuştur: "Üçüncü Umumi Müfettişliğge tayin edildim. Başbakanın doğu ilerlideki son seyahatinde yüksek ve derin bakışlarıyla buldukları idari, mali, ekonomik, bayındırlık, tarım, sıhhat, iskan ve diğer umumi kıymetlerdeki noksanları ikmal etmek şimdilik müfettişliğin esas programını teşkil eder. Çalışma arkadaşlarımızla hep birlikte bu yolda yürüyeceğiz. Celadet ve mefahirle dopdolu kocaman bir Türk tarihini sinesinde taşıyan doğu illerinde kahramanlar diyarında çalışmak halk yaşayışını yükseltmek, genişletmek ve bunlar içinde kendilerini káyıtsız, huzur ve sükun içinde bulundurmak daima göz önünde tutacağımız düsturlarımız olacaktır..."15

Yolculuk hazırlıkları tamamlanmıs ve 17 Eylül'de İstanbul'dan hareket ederek 21 Eylül'de Trabzon'a gelen Müfettişlik Heyeti, Trabzon'da törenlerle karşılanmış ve parti tarafından onuruna bir şölen tertip edilmişti. Tahsin Uzer de şölende bir konuşma yapmış, hükümetin bölgenin topyekün kalkındırılması için hazırlamış olduğu programlardan bahsetmesi halkı derin sevinçler içinde bırakmış, özellikle burada ileri gelenlerle temaslar kurarak onların desteğini almaya çalışmıştır ${ }^{16}$.

Tahsin Bey'in Trabzon'da göreve başlaması münasebetiyle çektiği telgrafta da görevi esnasında nasıl bir yönetim sergileyeceğine dair dikkate

12 Başbakanlık Cumhuriyet Arşivi, 030.18.01/57.70.15.

13 Başbakanlık Cumhuriyet Arşivi, 030.18.01/57.70.16; Koçak, Umumi Müfettişlikler..., s.155.

14 Mesela Erzurum halkının bu tavrı karşısında kendisi de şu telgrafı çekmiştir: "Vazifenin kutlanmasından sevinçliyim, kahraman evlatlarını sinesinde taşıyan Doğu ilerinde çalışmaktan neşeliyim saygılar ve sevgiler”, Erzurum Gazetesi, 12 Eylül 1935, No:3404.

15 “Eylül'ün 17'sinde İstanbul'dan hareket edeceğiz. Malî, sıhhî, iktisadî müşavirler beraberdir. 21 Eylül'de Trabzon'da bulunacağız 24'ünde Trabzon'dan hareketle bir gün Gümüşhane'de kalarak ertesi gün Erzincan'a yol alacağız. 26-27 Erzincan'dayız. 28'de Tercan'a uğrayarak Erzurum'da bulunacağız..." Erzurum Gazetesi, 19 Eylül 1935, No:3465.

16 Aymn Tarihi, 22 (1-30 Eylül 1935), s. 11. 
değer mesajlar vermiştir. Şöyle diyordu: "Milletin devlet içinde devlet adamlarından beklediği doğruluktur. Vazife, aşk ve imandır. Mesuliyet korkusudur. Bu mesuliyetin aşağıdan yukarıya değil yukarıdan aşağıya doğru olması hükümetçilik mantıkı icabıdır"17.

III.Umumi Müfettişlik Merkezi Erzurum idi. Müfettişlik programına göre mıntıkanın topyekün kalkındırılması ve bölgeler arasındaki kalkınmışlık farkını asgariye indirgeyebilmek için ekonomik, bayındırlık, eğitim ve sağlık gibi önemli alanlarda çalışmalar en kısa zamanda başlatılmalıydı. Dahası Cumhuriyetin bir çok nimetlerinden biri olan yaratıcılık ve yapıcılık kudretini bu mıntıka halkına tattırmak, bölgenin kalkındırılması için yerel idareler başta olmak üzere sivil örgütleri canlandırmak, halka rehber ve önayak olmak, çalışmak isteyen fakir bölge insanına iş sahası temin ve doğu vilayetlerinde görev yapacak memurların yaşam standardını artırmak programın esasını oluşturmaktayd ${ }^{18}$.

Tahsin Bey, bu sorumlulukla Trabzon'da göreve başladıktan sonra yanındaki kurmay heyetiyle bütün mıntıkayı bizzat dolaşmak suretiyle ${ }^{19}$ yerinde ve gerçekçi ve uygulanabilecek olan yatırımlar için acil eylem planları hazırlayarak Ankara'yla temasa geçmiştir.

Tahsin Bey, işlerin en kısa sürede ve başarıyla yapılabilmesi için elzem gördügüü işlerin başında yetki kargaşasının çözülmesi gelmekteydi. Bu maksatla kendi yetki alanındaki 8 vilayetin koordinesini sağlamak için de geniş yetkilerle donatılmasını Ankara'dan istemiştir. Bu istek biraz da bürokrasiyi azaltmak içindi. Tahsin Bey, Başbakan İsmet İnönü'ye 10 Mayıs 1936 yılında bu bağlamda bir rapor sunarak isteklerini ve durumu bildirmiştir. Tahsin Bey, bu maksatla şu öneriyi sunuyor: "Sekiz vilayet bir idare çerçevesi dahilinde mütalaa edilirse, hususi varidatlarının birleştirilmesi ve her vilayet umumi meclislerinden seçilen azalar ve valilerle birlikte Müfettişlik merkezinde umumi meclis halinde, beş senelik bir rogram çizmek üzere toplandıktan sonra, kendi aralarında ayıracakları daimi bir encümenin memleketin, Doğu'nun mefkureniz veçhile ilerlemesi için sırasile bu programı tatbik etmeleri, en kestirme bir yol olduğunu ve olacağını sonsuz saygılarımla arz ederim" ${ }^{20}$.

Göreve başlamasından birkaç ay geçmesine rağmen mıntıka hakkında edindiği bilgilere dayanarak Müfettişlik yetkilerinin yeniden düzenlemesi

17 Erzurum Gazetesi, 26 Eylül 1935, No:3466.

18 Başbakanlık Cumhuriyet Arşivi, 030.10.71.468.6.

19 Ayın Tarihi, 27 (1-29 Şubat 1936), s. 8.

20 Başbakanlık Cumhuriyet Arşivi, 030.10.68.452.2. "Vekaletle Müfettişlik arasında bu uzak ve yabancı duruş, benim vaziyetimi ne derece zorluğa sevk ediyorsa, iki taraflı muharebeye meram anlatmağa mecbur kalan valilerin endişelerini de artırmaktadır". 
için de 21 maddelik bir kanun layihası hazırlayarak Başbakan İsmet İnönü'ye sunmuştur ${ }^{21}$.

Tahsin Bey'in bu anlamda bir başka çalışması da diğer Umumi Müfettişlerle de temas kurarak onlarında görüşlerini almasıydı. Mesela Trakya Umumi Müfettişi Kâzım Dirik, hazırlanmakta olan kanun layihası için "Hazırlanan kanun layihasını okudum. Çok etraflıdır. Tamamıyla mutabıkım. Özmen'in düşüncelerine de ayrıca iştirak ediyorum... vs.,"22 demek suretiyle ortak bir akıl ile yetki ve sorumluluk meselesini halletmeye çalışmışlardır.

Tahsin Bey'in mıntıkada yapmak istediği işlerin başında şehirlerin imarı gelmekteydi. Bölgenin uzun yıllar işgal ve savaşlara maruz kalmasından dolayı harabeye dönmüş adeta köyleşmiş ve ilerleyen genç cumhuriyete yakışmayan görüntü kirliliğinden arındırmak ve bölgesi için mastır planları yapmak suretiyle de halka örnek olmak için yoğun çabalar içinde olmuştur.

Göreve başladığında müfettişlik merkezi Erzurum olmasına rağmen Erzurum'da müsait ve münasip bina bulunmamasından dolayı Trabzon'da geçici ikamet etmeleri, Tahsin Bey'in çalışmalarını etkilemekteydi ${ }^{23}$. Bu maksatla ve örnek bir şehir planı meydana getirmek için "Umumi Müfettişlik Grup İnşaatı” projesini başlatmıştır. Grup inşaatı, Umumi Müfettişlik, Kolordu Kumandanlığı, Jandarma Müfettişlik ve Kumandanlığı, Halkevi, Posta ve Telgrafhane, İnhisarlar Başmüdürlüğü, otel, lokanta, gazino, Müfettişi Umumi, Kolordu Kumandanı ve Müstahkem Mevki Kumandanı evleri, çift apartmanlı 21 adet memur ve subay evi ve bir ilk mektepten ibaret bir mahalle planının maketini ve buna ait iki milyon liraya baliğ keşifini ve projelerini hazırlattırarak Başbakan İsmet İnönü'ye takdim etmiştir. ${ }^{24}$ Hükümetin bu projeyi uygun görmesiyle inşaata başlanılmıştır ${ }^{25}$.

21 "Madde I. Umumi Müfettışler, mıntıkası dahilinde hükümetin vekili ve bütün vekillerin mümessilidir. Bu sıfatla başta valiler olmak üzere bütün memurlar kendisine karşı mesul ve gördükleri işlerden ve yaptıkları icraattan izahat ve hesap vermeğe mecburdurlar. Madde 3: Umumi Müfettiş, polis ve jandarma kıtaları gibi zabıta ve silahlı kuvvetleri ve mıntıkası içindeki asker kuvvetlerini icra kuvveti olarak kullanabilir...vs." Başbakanlık Cumhuriyet Arşivi, 030.10/70.468.8.

22 "Layihanın yedinci maddesine kültürel bakımında ilavesini lüzumlu buluyorum." Başbakanlık Cumhuriyet Arşivi, 030.10/70.463.3.

23 Içişleri Bakanlığı Arşivi, Sicil No:1222.

24 Başbakanlık Cumhuriyet Arşivi, 030.10/71.465.5. Başbakanlık Cumhuriyet Arşivi, 030.10/71.468.5; Başbakanlık Cumhuriyet Arşivi, 030.10/71.468.7; Başbakanlık Cumhuriyet Arşivi, 030.10/71.468.2.

${ }_{25}$ Başbakanlık Cumhuriyet Arşivi, 030.10/71.467.2. "Mektup ve telgraflarınızı okudum, müşavirinizi dinledim. Raporunuzu ayrıca okuyacağım, bütçe üzerinde umumi bir karar vermek zamanı yaklaştığından inşaata ait dilekleriniz üzerinde icab eden ve mümkün olan karara varılacaktır". Başbakanlık Cumhuriyet Arşivi, 030.10/71.468.9. "Esaslı bir plan ve program dahilinde başlanarak aynı şekilde üç sene mühim evrak ve birçok masraflar ihtiyarı 
Bu çalışmalarda dikkat çeken bir başka husus da Erzurum'un imar planını tanzim etmek üzere ünlü şehir planlamacısı Profesör Lamber'i birkaç kez Erzurum'a getirterek şehrin mastır planlarını hazıriatmasıydı ${ }^{26}$. Bundan başka Kars, Gümüşhane, Trabzon gibi vilayetlerinde gelecek imar planlarının yaptırıldığı görülmektedir ${ }^{27}$.

Bölgenin bol su, kanalizasyon, park, bahçe gibi alt yapı sorunları ve şehirlerin elektrikle aydınlatılması için hidrolik ve mekanik santrallerin kurulması içinde projelerin yapılması dikkat çekicidir ${ }^{28}$.

3. Umumi Müfettiş Tahsin Uzer'in "Doğu illerine hayat ve refah verecek" olan çalışmalar diye ifade ettiği en büyük projeleri şunlardır:

1-Sivas-Erzurum demiryoluna Erzurum cihetinden başlanılması.

\section{2-Trabzon Limanı'nın inşası}

3-İran transit yolunun yeniden canlandırılmasıdır.

Gerçekten de ülkelerin savunmasında, iktisadi kalkınmasında ve dünya ile bütünleşmesinde çağdaş bir proje olan demiryolları, Mustafa Kemal'in de "Demiryolu, memleketin tüfekten, toptan daha mühim bir emniyet silahıdır"29 dediği gibi cumhuriyetin en önemli projeleri arasında olacaktır. Atatürk, Doğu Anadolu demiryolları ile bölgeyi dünyaya açma hedefini daha 1924 senesindeki Sonbahar gezilerinde açıklamıştı. Gazi bir konuşmasında düşüncelerini şöyle açıklamıştı: "Baylar, bu kez Erzurum'a gelirken ayrı ayrı bölgelerden geçtim. Memleketin doğusu ile batısı ve merkezi arasındaki bağlantının, Cumhuriyet Hükümeti'nin yeterli göremeyeceği bir durumda olduğunu gördüm. Bunun için doğuyu öteki bölgelere bağlayan bir demiryolunun buraya kadar uzatılması Türkiye Cumhuriyeti için yaşamsal bir sorun olmaktadır...",30

“30 Ağustos 1930’da Ankara-Kayseri-Sivas demiryolụ gerçekleştirildi. Başvekil İsmet tarafından açılışı yapıldı. Hükümet, bu yolun Erzincan ve Erzurum'a uzatılması kararını ald ${ }^{31}$. Sivas-Erzurum Hattı inşası için 27 Mayıs 1933'te 2200 Sayılı Kanun çıkarılarak çalışmalara başlandı. Ancak

ile vücuda getirilmiş bulunan... Başbakanlık Cumhuriyet Arşivi, 030.10/70.468.10; Ayın Tarihi, 16 (1-31 Mart 1935).

26 Erzurum Gazetesi, 5 Haziran 1939, No:3596.

27. Başbakanlık Cumhuriyet Arşivi, 030.10/71.468.6.

28 "Erzurum, Kars dahil olduğu halde ufak büyük 16 kasabanın hidrolik ve mekanik elektrik projelerini Simens Şirketi'ne yaptırdım”. Başbakanlık Cumhuriyet Arşivi, 030.10/71.466.5; Başbakanlık Cumhuriyet Arşivi, 030.16/71.464.4.

29 Cihat İmer, Atatürk'ten Seçme Sözler, İstanbul, 1984, s.125.

30. Cumhurbaşkanı Gazi Mustafa Kemal Paşa'nın Sonbahar Gezileri, Çev. Nuri Onat, İstanbul, 1984, s.127.

31 Enver Konukçu, Mustafa Kemal Atatürk Döneminde Erzurum, Erzurum, 1999, s.375. 
hattın inşasına gerekli kaynağı bulmak önemli sorun oldu. Bunun için " 18 Kasım 1933'te 2463 Sayılı Sivas-Erzurum Hattı İnşası için Dahili İstikraz Akdi Kanunu" çıkarıldı ${ }^{32}$. Atatürk'ün hayali olan bu proje Tahsin Bey tarafından da sahiplenilmiş bürokratik işlemlerin tamamlanması için yoğun çabalar içinde olmuş ve 18 Mayıs 1936'da bu yolda emirler verilerek çalışmalar başlatılmıştı. 20 Temmuz 1937 'de Erzurum İstasyonunun temeli atılmıştı. Temel atma töreni basına şu şekilde yansımıştı: "Erzurum istasyonunun temel atma töreni Umumi Müfettiş Tahsin Uzer'le , Orgeneral Kazım Orbay, Korgeneral Ergüder, Vali H. İşcan'ın bulundukları çok kalabalık bir heyet huzurunda yapılmıștır... Temele, Umumi Müfettişimiz ve generaller ile vali ilk harcı atmıșlardır" "33. Günün imkanlarına rağmen inșaat binbir güçlükle sürdürülmüş, 1938 Erzincan $^{34} 1939$ 'da da Erzurum'a ulaşılmış 6 Eylül 1939'da ilk tren Erzurum'a gelmiş oldu ${ }^{35}$.

Tahsin Bey, Trabzon ve hinterlantının ekonomik bağlamda gelişmesi için olmazsa olmaz olarak gördüğü Trabzon Limanı için 17 Nisan 1939 Başvekil Dr.Refik Saydam'a hitaben bir mektup yazmıştı. Bu mektupta şu konuların önemi vurgulanmıştır:

1-Demiryollarının Erzincan ve Erzurum'a ulaşmasıyla birlikte zaten zor durumda olan yörenin ekonomik açıdan daha da fakirleşeceği,

2-Dünyada ekonomik krizlerin ve savaşların sonucunda sosyal ve ekonomik hayatın bölge insanını dahili ve harici birçok memlekete çalışmaya ittiği, bu durumun yöre halkının onurunu rencide ettiği,

3-Trabzon Limanı'nın yıllardan beri yapılmamasının, deniz ticaretine büyük darbeler vurduğu,

4-Liman transit yolunun uzun zamandan beri yapılamaması, siyasi birtakım durumlar yüzünden taşımacılığın Basra, Beyrut, Batum aracılığıyla yapılmasının yine bölge ticaretine çok büyük zararlar verdiğini,

5-Bölgeye soğuk hava, et, konserve, suni gübre fabrikalarının yapılmasının kaçınılmaz olduğu,

6-İzmir'de olduğu gibi Trabzon'da "Karadeniz" adıyla bir fuarın açılarak kıyı ve doğu halkına iktisadi ve içtimai bir hareket imkanının verilmesi" ${ }^{36}$.

32 Şaban Ortak, “Atatürk'ün Doğu Anadolu Demiryolu Politikası ve Erzurum'a Şimendiferin Gelişi”, Atatürk Universitesi Atatürk Ilkeleri ve Inkılâp Tarihi Enstitüsü Dergisi, (Mustafa Kemal Atatürk ve Erzurum Özel Sayısı), I/II, (Temmuz 1997), s.150.

${ }_{33}$ Ayın Tarihi, 44 (1-31 Temmuz 1937), s.9-10; Konukçu, Mustafa Kemal Atatürk..., s.375; Ayın Tarihi, 61 (1-31 I.Kanun ), 7

${ }^{34}$ Ayın Tarihi, 61 (1-31 I.Kanun 1938), s.6-9.

35 Ayın Tarihi, 71 (1-31 İlkteşrin 1939), s.12-15; Konukçu, Mustafa Kemal Atatürk.., s.375-377; Ortak, “Atatürk'ün Doğu Anadolu...”, s.151.

36 Başbakanlık Cumhuriyet Arşivi, 030.10/33.195.5. 
Kisaca bu mektupla memleketin bir tarafı kalkındırılmak istenirken, kalkınma hamlesinin memleketin diğer bir tarafını zor durumda bırakacak faaliyetten kaçınılması gerektiği, ya da bu zararın önlenmesi için gerekli alternatif tedbirlerin alınması hususunda gecikilmemesinin altı çizilmiştî ${ }^{37}$.

Üçüncü Umumi Müfettişi Tahsin Uzer'in rapor mahiyetli bu mektubu, 24 Nisan 1939 tarihinde işleme konulmuş ve kendisine Başbakan Dr. Refik Saydam tarafından şu cevabî yazı yazılmışıtır:

“17 Nisan 1934 tarihli mektubunuzu aldım. Trabzon Limanı'nın inşası meselesi hala müzakerede olan Ereğli Çatalağzı Limanı işleriyle beraber halli oluşmaktadır. Diğer hususat alakadar Vekaletlere not ettirilmiştir. Telafi ediyorum. Gözlerinden öperim."38

Cevabi yazıda da belirtildiği gibi Başbakan Dr.Refik Saydam'ın emriyle III.Umumi Müfettiş Tahsin Uzer' in istekleri, Ziraat Vekaleti, İktisat Vekaleti ve Ticaret Vekaletlerine gereğinin yapılması için gönderilmişti" ${ }^{39}$.

Tahsin Bey'in önemsediği bir diğer konuda İran Transit yolunun eski günlerine döndürülmesiydi. Yüzyıllarca doğuyu batıya bağlayan en kısa ve en rantable yol olan güzergahın canlandırılması için de bir çok kez Başbakanlığa raporlar sunmuş ve bunların takipçisi olmuştur. Çünkü, ona göre bölge ekonomisi ancak güzergah üzerindeki vilayet ve kasabaların kalkınmasıyla olacaktı. Bu maksatla 15 Ağustos 1936 tarihinde Başbakan İsmet İnönü'ye sunduğu rapor hayati bir önem taşımaktadır. Bu rapora göre;

"1-Gürcübulak-Trabzon yolunun bir an evvel ikmal ve tamiratı mütemadiyeye ehemmiyet verilmesi,

2-Trabzon Hususi Muhasebesinin almakta olduğu iskele resminin derhal kaldırılması,

37 Erdal Aydoğan, "Üçüncü Umumi Müfettiş Tahsin Uzer'in Trabzon'un Kalkınmasına Dair Başbakanlık’a Gönderdiği Bir Mektup” Trabzon ve Çevresi Uluslar arası Tarih-Dil-Edebiyat Sempozyumu, 3-5 Mayıs 2001, c.I, Trabzon, 2002, s.790.

${ }_{38}$ Başbakanlık Cumhuriyet Arşivi, Bakanlar Kurulu Kataloğu, 030.010/33.195.5.

39 Başbakanlık Cumhuriyet Arşivi, Bakanlar Kurulu Kataloğu, 030.010/33.195.5. Sayın Bay Muhlis Erkmen

Ziraat Vekili,

Sayın Bay Hüsnü Çakır

İktisat Vekili,

Sayın Bay Cezmi Ergin

Ticaret Vekaletleri'ne,

Üçüncü Umumi Müfettiş Bay Tahsin Uzer'in, Sayın Başvekile yazdığı 17.04.1939 tarihli mektubunda, yüksek vekaletlerini alakadar eden dilek hülasasının bir suretini Başvekilimizin emriyle derin saygılarımla takdim ederim.

Başvekalet Hususi Kalem Müdürü 
3-Trabzon Belediyesinin kapu parası ${ }^{*}$ namile aldı $\breve{g}_{1}$ resminin kaldırılması.

4-Gümrüğe verilen teminat sureti meselesinin nakli,

5-Benzin, lastik resimlerinin rakip yollar memleketlerindeki resim haddine indirilmesi,

6-Transit eşya muamelelerinin müdafaa pulu ve diğer pul resimlerinden muaf tutulmasi,

7-Yolların kışın kapanmamasını temin için fennî vesait ihzarı

8-Transit nakliyatının Nafia Vekaleti tarafından idaresi

9-Pasaport vize muamelatının basitleştirilmesi ve ucuzlatılması,

10-Müstahkem mevki mıntıkası formalitesile hudut zabiti tarafından yapılan vizenin süratle ve asgari bir zaman zarfında yapılmasının temini veya mümkünse ref'i ve ilgası,

11-Gümrük muamelesinin hudut üzerinde yapılabilmesi için Gümrüğün Kızıldize'den tam hududa kaldırılması

12-Vapur kumpanyaları nezdinde teşebbüsatta bulunularak transit ve eşya ve yolcuları için tenzilatlı bir tarife yapmalarının temini.

13-Güzergah üzerinde muayyen yerlerde muntazam birer otel ve lokanta açılması,

14-Trabzon'da bir serbest mintıka tesisi ${ }^{40}$,.

Tahsin Bey'in bu teklifi, 1934 yılında Rıza Şah'ın Türkiye'yi ziyaret etmesiyle gündeme gelmiş, Türkiye ile İran arasındaki diplomatik ve ticari münasebetlere de bir ivme kazandırmış olacaktı ${ }^{41}$. Bu çerçevede başlatılan çalışmalar da sonuçlandırılacaktır. Mesela Kızıldize Karaköse (A ğrı)Erzurum-Trabzon transit yolu 1937'de bitirilmiştir. Bu yolun açılışı resmi kayıtlarda şöyle yer bulmuştur: "Kızıldize'den ve Trabzon'dan hareket eden ve bu transit yolu üzerinde devamlı ve muntazam sefer yapacak olan ilk otobüslerin burada telakileri ile yapılan bu açılış törenine Umumi Müfettiş Tahsin Uzer riyaset etmiş ve sivil ve askeri erkan ve memurin ile kalabalık bir halk kütlesi iştirak etmiştir ${ }^{42}$.

Belediyelerin kamyonlardan her seferinde aldığı resim. Birbuçuk liradır.

4) Başbakanlık Cumhuriyet Arşivi, 030.10./71.465.1.

${ }^{41}$ Ömer Erden, "1934 Yılında Trabzon-Erzurum-Tebriz Transit Yolu ve Riza Şah'ın Erzurum'a Gelişi”, 23 Temmuz Erzurum Kongresi ve Kurtuluştan Günümüze Erzurum I.Uluslararası Sempozyumu, (23-25 Temmuz 2002-Erzurum), Ankara, 2003, s.847.

${ }^{42}$ Aym Tarihi, 436 (1-31 Haziran 1937), s.6. 
Tahsin Bey'in ekonomik bağlamda yaptığı yatırımlardan bazıları Erzurum'da iplik fabrikası, Trabzon'da et ve soğuk hava, balık yağı, suni gübre fabrikaları, Murgul bakır ve kuvars madenlerinin yeniden işletilmesi, Kars'ta, Iğdır'da Erzurum'da ihracat - ticaret birlikleri, kooperatifler, Iğdır Ovası'nda pamuk üretimi, Iğdır bölgesine Serdarabat Barajı'nın fonksiyonel hale getirilmesi, Erzurum'da şeker fabrikası soğuk et ve konserve fabrikası, Rize ve Çoruh vilayetlerinde iskeleler ${ }^{43}$ yapılması için birçok kez Ankara'ya gitmiş, işlerine aksamaması için işleri yakından takip etmiştir.

Ayrıca bölge halkının en büyük geçim kaynağı olan tarım ve hayvancılığın da geliştirilmesi için bazı girişimleri dikkat çekicidir. Mesela Karadeniz halkının en büyük gelir kaynaklarından olan mısır ve fındık alımlarının devlet tarafından desteklenmesi ve çiftçiye kredi verilmesi için çalışılırken ${ }^{44}$ Kars, Ağrı ve Gümüşhane gibi vilayetlerde üreticilerin hava şartlarından dolayı zarar gören çiftçilerin desteklenmesi ve buralarda tarımda makinalaşmanın desteklenmesini ısrarla desteklemiştir ${ }^{45}$.

Umumi Müfettiş Tahsin Bey, bütün bu özverili çalışmalara paralel olarak yapılması kaçınılmaz olan işlerinde desteklenmesine çalışmıştır. Bu bağlamdaki çalışmalar daha çok memur, esnaf ve çiftçilerin hayat şartlarının iyileştirilmesi, vergiler ve harcırahlar üzerinde yaptığı çalışmalar dikkat çekicidir: Bunlar:

1-Hükümet konaklarının inşası ve memur evlerinin meydana gelmesi için her sene ikişer yüzbin lira verilmesi.

2-Arazi vergisinin hususi idarelere devri.

3-Sayım vergisinin indirilmesi

4-Bina ve meskenler için 300.00 lira verilmesi.

5-Harcırah tahsisatının geniş tutulması.

6-Sekiz vilayetin su, elektrik, bataklık kurutulması, müfettişlik ve hükümet devair inşaatı, hapishanelerin tecricen yenilenmesi, şehir planları ile umumi sıhhate ait müstacel işlerin görülmesi için iki veya üç senede ikişer milyon liranın umumi müfettişlik mıntıkasına tahsisi”" ${ }^{{ }^{4} 6}$ gibi konulardı.

${ }^{43}$ Başbakanlık Cumhuriyet Arşivi, 030.10./71.465.6. "Erzurum'da yeni yapılan büyük kremit ve tuğla fabrikasının açılma merasimi dün vali Haşim tarafından tezahüratla yapıldı". Ayın Tarihi, 48 (1-30 Sonteşrin 1937), s.9. "Hopa iskelesinin devlet bütçesinden yapılması için vaki dilekler üzerine bu ihtiyacı yakından gören Bakanlar iskelenin esaslı bir şekilde yapılması doğu illeri için çok faydalı olacağı neticesinde vermişlerdir”. Ayın Tarihi, 34 (1-30 Eylül 1936), s.6.

44 Başbakanlık Cumhuriyet Arşivi, 030.10/771.465-7.

45 Başbakanlık Cumhuriyet Arşivi, 030.10./70.462-1.

46 "Sayım vergisinden 2897 sayılı kanunla tenzilat yapılmıştır" vs. Başbakanlık Cumhuriyet Arşivi, 030.10./71.463-9. 
Umumi Müfettiş Tahsin Bey’in kendi bölgesinde yaptığı faaliyet alanlarından bir diğeri bu eğitim, kültür ve sağlıktır. Bu alanlarda da kendi valilikleriyle yada bizzat gezip yerinde tespitlerini Başbakanlığa ileterek bunların hayata geçmesine çalışmıştır. Bu bağlamda 1 Mayıs 1936 yılında Trabzon'dan Başbakanlığa gönderdiği raporunda şu tekliflerini ileterek gerekenin yapılmasını istemiştir. Buna göre, "Yarım asır Çarlık idaresinde kaldıktan sonra tekrar anavatana kavuşan halk ve baştan başa Karadeniz evlatları iki elinizden öperek ruhi gıdaları olan kültür için büyük yardımlarınızı yalvarıyor. Her kaza mutlak bir orta mektep istiyor. Her kaza merkezinde ya bir ya iki mektepte 300'den 700'e kadar çocuk bulunduğunu gözümle görmekteyim. Her yıl bunlardan 40-80 çocuk diploma alıyor, bunlardan ancak \% 1'i ve ikisi vilayet merkezlerine gidebilecek tahsillerine devam ediyor. Diğerleri daha doğrusu hemen hepsi ilk okuma ve mahallerinde kalıyorlar. Ve derin istırap çekiyorlar. Geçende Akçaabat ve bu defa Sürmene, Of, Pazar, Rize ve Hopa merkezlerine uğradığımda dil birliği ile bana aynen şu sözleri söylediler: Başbakanımızdan orta mektep isteriz..." ${ }^{, 47}$.

$\mathrm{Bu}$ çerçevede yapılan istekler Başbakanlıkça desteklenmiş ve bölgenin bir çok kazasında okulların yapılması için ödenekler çıkarılmış ve inşaatlara başlanılmıştır. Mesela 29 Temmuz 1937 eğitim öğretim yılında Erzurum Vilayeti dahilinde üç kaza ve beş mektebin, Kars Vilayetinde iki kaza ve dört mektebin, Artvin Vilayeti'nde iki nahiye konağı ile üç mektebin, Erzurum'da akıl ve frengi hastaneleri, Ağrı Vilayeti'nin Tutak Kazası'nda belediye dairesinin ve Eleşkirt köylerinde dört okulun ihalesi yapıldı ğı, Göle'de ilk mektebin temel atma töreninin yapılarak inşaatlara hız verildiği bildirilmiştir ${ }^{48}$.

Yine bu çalı̧̧malar resmi kayitlara şöyle geçmiştir: “Trabzon'da yeni Trabzon Lisesi'nin temel atma merasimi bugün binlerce halkın iştirakiyle yapılmış ve Umumi Müfettiş Tahsin Uzer temele ilk malayı vurmuştur" ${ }^{\text {"49 }}$.

Çağdaşlaşma yolunda yapılan çalışmalar genç cumhuriyetin ana hedefleriydi. Birçok problemin yaşand 1 ğ 1 bu dönemlerde yeni arayışlar içinde olan hükümetler demokrasiyi tabana yayma doğrultusunda halk eğitimine ağırlık veren denemeleri ivme kazanmıştır. ${ }^{50}$ İşte bu bağlamda hayata geçirilen Halkevleri projesi bölgeler arasındaki eğitim ve kültür alanındaki kalkınmışlık farkını da asgariye indirme çabası Üçüncü Umumi Müfettişlik için de önemsenmesi gereken bir konuydu.

Bu maksatla Erzurum, Artvin, Gümüşhane, Bayburt, Karaköse, Kars merkezlerinde Halkevleri, ilçelerde ve beldelerde halk odalarının açılmasını

47 Başbakanlık Cumhuriyet Arşivi, 030.10/71.464.1.

48 Başbakanlık Cumhuriyet Arşivi, 030.10/71.466.7.

49 Ayın Tarihi, 55 (1-30 Haziran 1937), s.7.

50 Anıl Çeçen, Halkevleri, Ankara, 1990, s.95. 
teşvik etmiştir. Bu şehirlerde bunlar olurken Trabzon gibi önemli bir şehirde halkevinin açılamamasına üzüntüleri ileterek, Dahiliye Vekaleti'nden burada halkevinin açılması için başlattığı projenin desteklenmesini istemiştir ${ }^{51}$.

Mesela 1934 yılında Nurlu Şükrü'nün evinde açılan Erzurum Halkevi, kuruluşundan üç yıl sonra kendi binasına sahip olmak için çalışmalar başlatmış, sonunda da Erzurum'da Umumi Müfettişlik binalarının temel atma törenleri çerçevesinde Umumi Müfettiş Tahsin Uzer'in büyük yardımlarıyla 10 Temmuz 1937 yılında halkevinin temelleri atılmış, 1939'da da inşaat bitirilmiştir ${ }^{52}$.

Tahsin Bey, bir taraftan bu gibi alt yapı çalışmalarının tamamlanması için çalışırken diğer taraftan da halkın bilinçlenmesi için bazen kendisi ${ }^{53}$ bazen de dışardan konusunda uzmanları şehirlere davet ederek istifade etme gayreti içinde olmuştur ${ }^{54}$. Basın yayın alanında hem halkevi dergilerinin çıkarılmasını hem de yerel gazetelerin çıkarılması için teşvik etmiş destek olmuştur $^{55}$. Mesela Erzurum'da Doğu Gazetesi çıkarılması desteklenmiştir. Günlük çıkan bu gazete daha sonra Ulus namıyla çıkarılası için ilgili vekaletlerden destekler aramıştır. Tahsin Bey, bir yazısında şöyle diyordu: "Esasen Erzurum Vilayeti bu gazeteyi güçlükle idare ve idare ediyordu. Erzurum'da Ulus'un bu suretle himayenizde kalması çok yerinde ve değerinde manevi bir eseriniz olacaktır" ${ }^{\text {"56 }}$. Ve Tahsin Bey, bölgenin her türlü ihtiyacı için binlerce önemli projeyi böylece hayata geçirme gayretinden vazgeçmemiş sonrakilere örnek olmuştur.

Görüleceği gibi Tahsin Bey'in dört yıllık görevi süresince Müfettişliklerin kuruluş gayesine uygun binlerce eser imza atmış olması fevkalade önemlidir. Cumhuriyet aydınının, devlet adamının nasıl olması gerektiği hakkında bir çok ipuçları vermiştir.

Tahsin Bey, 1935 yılında 1939 yılının sonuna kadar bu görevde kalır. Tahsin Bey, 3 Kasım 1939 tarihinde de sağlık nedeniyle görevinden ayrılır, birkaç ay sonra da vefat eder. Yerine 30 Haziran 1940 tarihinde Dahiliye Vekaleti Müsteşarı Nazif Ergin atanır ${ }^{57}$. Ve Tahsin Bey'in çalışmaları devam ettirilir.

5ı Başbakanlık Cumhuriyet Arşivi, 030.10./71.468.1. Benzer bir isteği de Ağrı'da açılan halkevi için istemiştir. "Bu bina bitmek üzeredir. Fakat borçları kalmıştır..." Başbakanlık Cumhuriyet Arşivi, 030.10./71.466.10.

52 Erdal Aydoğan, "Erzurum Halkevi'nin Kuruluşu ve Faaliyetleri”, 23 Temmuz Sempozyumu, (23-25 Temmuz 2002-Erzurum), Ankara, 2003, s.793.

53 Erzurum Gazetesi, (14 Mayıs 1936), No:3496; Erzurum Gazetesi (4 Haziran 1936), No:3499.

54 Ayin Tarihi, 32 (1-31 Temmuz 1936), s.6.

55 Erzurum Gazetesi (16 Eylül 1937), No:3564; Erzurum Gazetesi (26 Ağustos 1937), No:3561.

56 Başbakanlık Cumhurivet Arşivi, 030.10./71.468.1.

57 Koçak, Umumi Müfettişlikler, s.159. 